\title{
Long-term biventricular circulatory support with POLVAD-MEV paracorporeal pulsatile pumps. Single-centre experience
}

\author{
Tomasz K. Urbanowicz, Hanna Baszyńska-Wachowiak, Anna Olasińska-Wiśniewska, Marcin Misterski, \\ Sebastian Stefaniak, Marcin Ligowski, Marek Jemielity
}

Department of Cardiac Surgery and Transplantology, Poznan University of Medical Sciences, Poznan, Poland

Kardiochirur Torakochir Pol 2020; 17 (2): 101-104

\begin{abstract}
Introduction: Severe heart failure decompensation requires circulatory mechanical support in emergency situations. Polish paracorporeal pulsatile pumps, POLVAD-MEV, are designed for biventricular end-stage heart dysfunction.

Aim: To evaluate long-term POLVAD-MEV therapy by multiple pump exchange in patients on a transplant list.

Material and methods: There were 3 patients in INTERMACS level 1 referred for emergency POLVAD-MED implantation due to acute heart failure deterioration. The paracorporeal pulsatile mechanical support was applied due to severe biventricular dysfunction.

Results: They were supported by paracorporeal biventricular POLVAD-MEV pumps for 438, 473 and 394 days until heart transplantation. During the hospitalisation the pumps required multiple pumps exchanges within $29 \pm 10$ (4-49) day intervals.

Conclusions: POLVAD-MEV paracorporeal pulsatile pumps present a safe option for long-term circulatory support in a selected group of patients. Therapy requires pump exchange but enables survival while awaiting a heart transplant.
\end{abstract}

Key words: heart failure, BIVAD, POLVAD, heart transplantation.

\section{Introduction}

Cardiovascular diseases are one of the leading health problems in developed countries [1]. Congestive heart failure is becoming nowadays a major clinical concern. Heart transplantation is effective therapy for end stage disease with satisfactory life expectancy. As the waiting lists for organ donors are long, patients with acute decompensation must be treated with other ways including mechanical circulatory support. This is a reasonable option especially in those patients in end stage disease assigned to levels 1 and 2 on the INTERMACS (Interagency Registry for Mechanical

\section{Streszczenie}

Wprowadzenie: Ciężka niewydolność serca może wymagać stosowania mechanicznego wspomagania krążenia w sytuacjach krańcowej jego dysfunkcji. Pneumatyczne, pulsacyjne pompy POLVAD-MEV umożliwiają leczenie dwukomorowej niewydolności krążenia w okresie krótkotrwałym.

Cel: Ocena bezpieczeństwa długoterminowej terapii systemem pneumatycznych pomp POLVAD-MEV u osób oczekujących na przeszczepienie narządowe.

Materiat i metody: Ocenie poddano 3 chorych poddanych operacji implantacji dwukomorowego mechanicznego wspomagania krążenia w klasie INTRERMACS 1 jako terapii ze wskazań życiowych.

Wyniki: Średni czas wspomagania krążenia serca za pomocą pomp POLVAD-MEV wyniósł 438, 473 i 394 dni. Do czasu przeszczepienia narządowego pompy wymagały wielokrotnych regularnych wymian co $29 \pm 10$ (4-49) dni.

Wnioski: POLVAD-MEV jest systemem pneumatycznych pomp pulsacyjnych pozwalających na ochronę życia chorego do czasu przeszczepienia narządowego, nawet w okresie długotrwatej terapii.

Słowa kluczowe: niewydolność serca, BIVAD, POLVAD, przeszczep serca.

Assisted Circulatory Support) scale [2, 3]. The number of left ventricle assist device (LVAD) implantations has been exceeding the number of organ transplantations in recent years [4]. The concomitant right ventricle failure is estimated to be as high as $13-40 \%$ [5]. Patients suffering from biventricular failure require either total artificial heart implantation or biventricular paracorporeal pulsatile pumps.

POLVAD-MEV is a paracorporeal pulsatile pump, designed for short-term circulatory support. We present the results of long-term therapy as a bridge to transplantation based on repetitive pump exchange.

Address for correspondence: Tomasz K. Urbanowicz MD, PhD, Department of Cardiac Surgery and Transplantology, Poznan University of Medical Sciences, Poznan, Poland, e-mail: tk.urbanowicz@gmail.com Received: 4.05.2020, accepted: 9.06.2020. 


\section{Aim}

The aim of the study was to evaluate long-term POLVAD-MEV therapy by multiple pump exchange in patients on a transplant list.

\section{Material and methods}

There were three patients admitted to our hospital due to cardiogenic shock secondary to heart failure decompensation requiring emergency mechanical circulatory support. All the procedures were performed through median sternotomy. After heparin administration, cardiopulmonary bypass (CPB) was initiated. The left-sided cannulas were sutured into the ascending aorta and left atrial appendage. The right-sided cannulas were sutured into the pulmonary trunk and right atrium appendage. The distal parts of all four cannulas were transferred through skin incisions and connected to pumps after deairing. The function of the pumps was initiated carefully and patients were weaned off CPB. The heparin was reversed by protamine according to activated clotting time (ACT) values. After chest closure, patients were transferred into an intensive care unit (ICU). Heparin infusion was restored on the following day in the ICU. On the second day, the antiplatelet therapy (acetylsalicylic acid) was started. The oral anticoagulants were started on the third postoperative day and continued according to the international normalized ratio (INR) ratio.

The first patient, a 35-year-old man with dilated cardiomyopathy, was admitted to the hospital due to advanced symptoms of biventricular heart failure. He presented with shortness of breath, profound oedemas with $20 \mathrm{~kg}$ weight gain, wheezing and inability to walk more than $10 \mathrm{~m}$ and profound tachycardia. Inotropic support combined with intravenous diuretics was unsuccessful during the initial 14 days of therapy in the cardiological unit. On echocardiography left and right ventricles diameters were $89 \mathrm{~mm}$ and $45 \mathrm{~mm}$, respectively. Left ventricle ejection fraction (LVEF) was estimated as $10 \%$. He presented with INTERMACS status 1 . The team of cardiac surgeons, cardiologists and anaesthesiologists decided to refer the patient for emer-

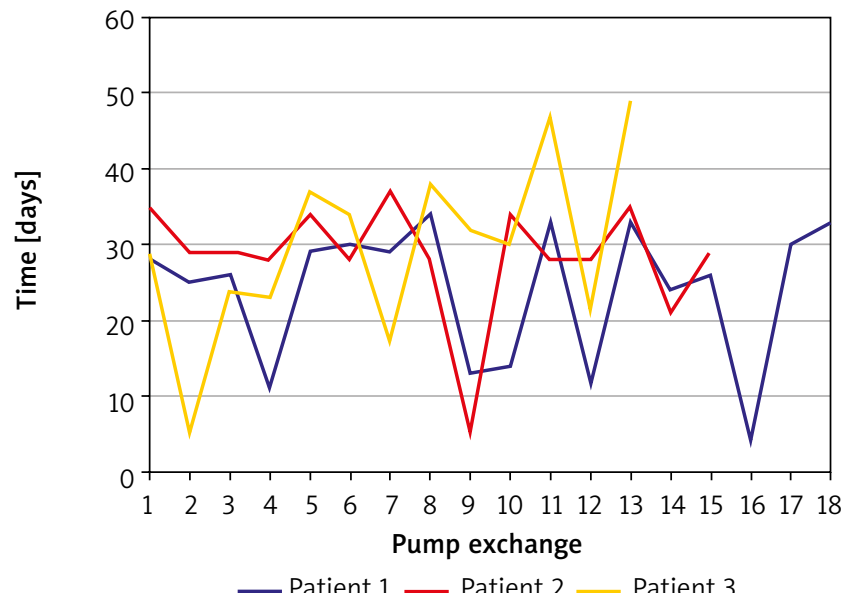

Figure 1. Mean time of pump function gency biventricular assist device (BIVAD) implantation. The POLVAD-MEV left-sided and right-sided pumps were implanted.

The second patient was an 18-year-old man, admitted to the hospital due to fulminant myocarditis not responding to pharmacotherapy during 16 days of hospitalization on the cardiology ward. He presented with 1-month history of shortness of breath, chest pain and palpitations before admission to the cardiology ward. The LVEF was $15 \%$ with left ventricle (LV) dilatation to $75 \mathrm{~mm}$ and right ventricle diameter of $30 \mathrm{~mm}$. His clinical status was assessed as INTERMACS 1. Biventricular support was the only therapeutic option for him due to the active phase of myocarditis.

The third patient was a 42-year-old man with cardiogenic shock secondary to congestive heart failure due to dilated cardiomyopathy who was referred for MCS implantation. He was initially treated with intravenous catecholamines and awaited heart transplantation for 49 days. He was temporarily supported by an intra-aortic balloon pump (IABP) which was finally removed due to leg ischaemia. His clinical status was stable in INTERMACS 2 but in time he deteriorated with multiorgan failure including kidney and liver insufficiency not responding to conventional therapy. He was referred for biventricular POLVAD-MEV implantation as a rescue therapy.

\section{Results}

All 3 patients survived until heart transplantation. All pumps were visually checked by physicians on daily routines for risk of thrombus formation. INR ratio was routinely monitored and anticoagulation therapy involving oral anticoagulant and antiplatelet drugs was adjusted.

In the first patient, during his hospitalization the pumps were changed 18 times with mean intervals of $29 \pm 9$ (4-34) days (Figure 1). During the time of 438 days of support, head computed tomography was negative for any thrombo-embolic events during this time. His prolonged awaiting for heart transplantation during the hospitalization was disturbed by infection episodes (Staphylococcus epidermidis and Enterococcus faecalis) that were successfully treated with antibiotics. Finally, the patient was transplanted with the Lower-Shumway technique after 210 minutes of cold organ ischaemia. Postoperatively he required ECMO support for 4 days that was successfully weaned. His further postoperative time was uneventful with satisfactory results of endomyocardial biopsies. The patient was treated with a standard triple immunosuppressive protocol including a calcineurin inhibitor, antiproliferative drug (mycophenolate mofetil) and steroids. He was discharged on the $51^{\text {st }}$ postoperative day in good clinical status (New York Heart Association - NYHA I). His overall hospitalization time was 503 days.

Two endomyocardial biopsies during initial mechanical support were performed in the second patient due to the active phase of myocarditis. The results, obtained at 1-month intervals, presented with active and healing phases of myocarditis, respectively. On repeat echocardiograph- 
ic examinations no heart recovery was detectable. Neither the diameter of both ventricles, nor the ejection fraction improved through the whole period. Finally, the patient was qualified for transplantation. During the hospitalization, pumps were exchanged 15 times at mean intervals of $28 \pm 8$ (5-37) days (Figure 1). Heart transplantation was performed with the Lower-Shumway technique with organ cold ischaemic time of 275 minutes. Postoperative course was uneventful with results of myocardial biopsies negative for rejection. He was treated with a standard triple immunosuppressive protocol including a calcineurin inhibitor, antiproliferative drug (mycophenolate mofetil) and steroids. He was discharged home on the $26^{\text {th }}$ postoperative day presenting NYHA clinical stage I. His overall hospitalization time was 473 days.

The third patient developed brain ischaemia localized in the temporal lobe, confirmed by computed tomography imaging, postoperatively. During postoperative recovery he was treated with dual antithrombotic therapy including oral anticoagulants and aspirin. During his hospitalisation, the pumps were exchanged 13 times at mean intervals of $29 \pm 12$ (5-49) days (Figure 1). His post-implantation period awaiting heart transplantation was disturbed by infection episodes (Staphylococcus epidermidis and Enterococcus faecalis) and one episode of femoral injury during rehabilitation. After 394 days of mechanical support, he was successfully transplanted. Unfortunately, he died 59 days after due to pulmonary aspergillosis infection that was not responding to antibiotic therapy, followed by secondary multiorgan failure.

\section{Discussion}

We present three patients with end stage biventricular heart insufficiency who would not have survived until heart transplant without mechanical support due to their severe clinical deterioration.

Patients were referred for POLVAD-MEV implantation after clinical deterioration not responding to conventional therapy of acute heart decompensation including catecholamine infusion. They were in INTERMACS class 1 . One of the patients was treated with an intra-aortic balloon pump (IABP). The POLVAD-MEV was chosen as a preferred method for mechanical circulatory support due to biventricular dysfunction which ruled out the possibility of continuous flow pump implantation. Pulsatile pumps were applied as bridge therapy for transplantation but due to patients' profound clinical deterioration, including multiorgan failure, long-term reconvalescence was expected.

Echocardiography revealed poor left ventricle function with low ejection fraction estimated as $10 \%, 15 \%$ and $12 \%$ in these 3 patients. Left and right ventricle diastolic diameters were $81 \mathrm{~mm}, 76 \mathrm{~mm}, 69 \mathrm{~mm}$ vs. $42 \mathrm{~mm}, 43 \mathrm{~mm}, 41 \mathrm{~mm}$, respectively. Right ventricle function evaluation was additionally estimated on measurements of tricuspid annular plane systolic excursion (TAPSE).

Our decision concerning biventricular support was based on echocardiographic data and direct evaluation of right ventricle function after sternotomy during surgery. Moreover, one patient was operated on due to myocarditis fulminant in its active phase.

The number of patients suffering from heart insufficiency is increasing in developed countries [6]. The 1-year mortality rate is as high as $6 \%$ and $23 \%$ for chronic and acute heart failure patients despite advances in medical therapy [7]. Congestion is a meaningful factor of re-admissions but its prognostic value for future decompensations is low [8]. Decompensation followed by cardiogenic shock often has poor prognosis. Adequate haemodynamic support is crucial for acute decompensations. Clinical deterioration in the end stage phase of congestive heart failure requires mechanical circulatory support to regain adequate blood perfusion. Decompensation of chronic heart failure is still a primary indication for mechanical support according to EUROMACS registry, with up to $20 \%$ of patients requiring biventricular support [9]. According to the INTERMACS scale 90-day survival in levels 1 and 2 are 18\% and $15 \%$, respectively [10]. Those low percentages explain the necessity for an urgent solution involving mechanical support.

Fulminant myocarditis is also a disease that necessitates immediate intervention to treat a haemodynamic compromise [11, 12]. This inflammatory cardiomyopathy may present as the fulminant type with mortality reaching 25-40\% [13]. Aggressive therapy including mechanical support in severe cases has already been advocated [14, 15]. Myocarditis is an inflammatory disease of whole heart muscle including both ventricles, so in our opinion, BIVAD was the preferable option. The second repeated biopsy, performed after 2 months of pump support, revealed healing processes, reaffirming the necessity of long-term mechanical support. Left ventricle unloading is important to reduce wall stress and volume overload to enable myocardial healing [16]. In our approach, the left ventricle was unloaded by left atrial cannulation, despite routine left ventricle apex cannulation [17]. In the healing phase of myocarditis, the dilated ventricle is supposed to significantly reduce the diameter, which makes this position questionable as for cannula positioning.

There are a few possible short-term mechanical support devices including IABP and veno-arterial extracorporeal membrane oxygenation ( $v$-a ECMO). Both are available only for short support, and are insufficient for the patients who we present in terms of maintaining the improvement and time for transplantation. For the presented patients venous-arterial extracorporeal membrane oxygenation ( $v$-a ECMO) was not an option due to time-limited safety of this mechanical support. We believe that $v-a$ ECMO is an excellent option for either postoperative low cardiac output syndrome (LCOS) or cardiogenic shock secondary to acute myocardial infarction. The best results of this type of support are achieved within 1-2 weeks of therapy. Patients requiring more than 2 weeks of mechanical support are referred for either pulsatile or continuous flow pumps. The former are designed for left ventricle support in patients 
presenting with INTERMACS class 3 or 4 and satisfactory right ventricle function.

All 3 patients presented right ventricle failure; therefore the LVAD was not an optimal therapeutic strategy. Combined LVAD and right ventricle assist device (RVAD) support is either temporary or presents poor long-term results.

The pumps were exchanged after every 30 days according to manufacturer suggestions. Pumps were visually checked on a daily basis by a physician. The right pump was more prone to thrombi formation than the left throughout the therapy period. The inflammatory state including wound infection promoted more often pump exchange due to thrombotic debris. The overall mean time for pump function in our patients was $27 \pm 9$ (4-49) days (Figure 1). Repeated pump exchange allowed us long-term support with relatively good results. Therapy was sufficient for patients to undergo proper rehabilitation and also to regain function of the other organs (kidneys and liver).

The time of pump function was characterised by a wide range from 4 to 49 days. The discrepancy was related to infection episodes. We found that thrombus formation in pumps was related to inflammatory status of the patients. Wound infection episodes treated with antibiotics were inversely correlated. All patients were on standard dual anticoagulation therapy including oral anticoagulant (OAC) and antiplatelet drug (aspirin $75 \mathrm{mg}$ daily). The OAC dosing was adjusted to routine INR measurements with the preferable range $2.5-3.5$. If the INR was measured to be below 2.5 , according to our protocol low molecular weight heparin (LMWH) was added together with an increased dose of OAC.

Our study is the first presentation of long-term circulatory support by pulsatile paracorporeal pumps. Frequent pump exchanges were necessary as the thrombotic debris were found on routine visual check-ups. Paracorporeal support therapy is possible only during in-hospital stay and prolonged hospitalisation is the major disadvantage for these patients.

\section{Conclusions}

POLVAD-MEV paracorporeal pulsatile pumps present a safe option for long-term circulatory support in a selected group of patients. Therapy requires pump exchange but enables survival while awaiting a heart transplant.

\section{Disclosure}

Authors report no conflict of interest.

\section{References}

1. Noly PE, Ben Ali W, Lamarche Y, Carrier M. Status, indications, and use of cardiac replacement therapy in the era of multimodal mechanical approaches to circulatory support: a scoping review. Can J Cardiol 2020; 36: 261-269.

2. Ton VK, Xie R, Hernandez-Montfort JA, et al. Short- and long-term adverse events in patients on temporary circulatory support before durable ventricular assist device: an IMACS registry analysis. J Heart Lung Transplant 2020; 39: 342-352.

3. Jarmoszewicz K, Siondalski P, Pawlaczyk R, et al. Treatment of acute heart failure. Clinical cases. Kardiochirur Torakochir Pol 2008; 5: 52-55.

4. Melton N, Soleimani B, Dowling R. Current role of the total artificial heart in the management of advanced heart failure. Curr Cardiol Rep 2019; 21: 142.

5. Shah P, Ha R, Singh R, et al. Multicenter experience with durable biventricular assist devices. J Heart Lung Transplant 2018; 37: 1093-1101.

6. Kurmani S, Squire I. Acute heart failure: definition, classification and epidemiology. Curr Heart Fail Rep 2017; 14: 385-392.

7. Crespo-Leiro M, Anker S, Maggioni A, et al. Heart Failure Association (HFA) of the European Society of Cardiology (ESC). European Society of Cardiology Heart Failure Long-Term Registry (ESC-HF-LT): 1-year follow-up outcomes and differences across regions. Eur J Heart Fail 2016; 18: 613-25.

8. Rubio-Gracia J, Demissei BG, Ter Maaten JM, et al. Prevalence, predictors and clinical outcome of residual congestion in acute decompensated heart failure. Int J Cardiol 2018; 1: 185-191.

9. Vierecke J, Gahl B, de By TMMH, et al. Results of primary biventricular support: an analysis of data from the EUROMACS registry. Eur J Cardiothorac Surg 2019; 56: 1037-1045.

10. Adamo L, Nassif M, Tibrewala A, et al. The Heartmate Risk Score predicts morbidity and mortality in unselected left ventricular assist device recipients and risk stratifies INTERMACS class 1 patients. JACC Heart Fail 2015; 3: 283-290.

11. Ammirati E, Veronese G, Cipriani M, et al. Acute and fulminant myocarditis: a pragmatic clinical approach to diagnosis and treatment. Curr Cardiol Rep 2018; 20: 114.

12. Olejniczak M, Schwartz M, Webber E, et al. Viral myocarditis-incidence, diagnosis and management. J Cardiothorac Vasc Anesth 2020; 34: 1591-1601.

13. Ammirati E, Cipriani M, Camic PG. New concepts in fulminant myocarditis and risk of cardiac mortality. Oncotarget 2017; 8: 84624-84625.

14. Mody KP, Takayama H, Landes E, et al. Acute mechanical circulatory support for fulminant myocarditis complicated by cardiogenic shock. J Cardiovasc Transl Res 2014; 7: 156-164.

15. Litwiński P, Woźniewicz B, Religa G, et al. Polish ventricular assist device (POLVAD) support for the treatment of cardiogenic shock in patients with myocarditis. Kardiochir Torakochir Pol 2005; 2: 33-40.

16. Tschöpe $C$, Van Linthout $S$, Klein $O$, et al. Mechanical unloading by fulminant myocarditis: LV-IMPELLA, ECMELLA, BI-PELLA, and PROPELLA Concepts. J Cardiovasc Transl Res 2019; 12: 116-123.

17. Catena E, Paino R, Milazzo F, et al. Mechanical circulatory support for patients with fulminant myocarditis: the role of echocardiography to address diagnosis, choice of device, management, and recovery. J Cardiothorac Vasc Anesth 2009; 23: 87-94. 